\title{
CARACTERIZAÇÃO HIDROGEOLÓGICA E SIMULAÇÃO NUMÉRICA EM ÁREA DO DISTRITO INDUSTRIAL DE PAULÍNIA (SP)
}

\author{
Elias Hideo Teramoto ${ }^{1}$, Kiang Hung Chang ${ }^{2}$
}

\begin{abstract}
RESUMO Em área contaminada por hidrocarbonetos, situada no município de Paulínia (SP), a migração dos contaminantes e a eficiência do sistema de bombeamento são governadas pela heterogeneidade litológica do aqüífero local, constituído por rochas do Subgrupo Itararé e sedimentos cenozóicos correlatos à Formação Rio Claro. Desta forma, o entendimento da heterogeneidade e das propriedades hidráulicas que caracterizam esse aqüífero é essencial para a otimização e o aprimoramento de processos de remediação. Com vistas a caracterizar o contexto hidrogeológico local, foi elaborado modelo hidrogeológico conceitual, por meio da integração de dados provenientes de técnicas tradicionais de investigação - métodos geofísicos, monitoramento dos níveis piezométricos de poços de monitoramento, descrições geológicas e análises granulométricas -, obtendose, assim, a dinâmica de fluxo local e a distribuição dos litotipos do aqüífero e seus valores de condutividade hidráulica. Foram ainda realizadas simulações numéricas de fluxo em regime permanente, utilizando o software Visual Modflow, que emprega o método de diferenças finitas para testar o modelo conceitual concebido. A simulação numérica apresentou excelentes correlações entre os valores de cargas hidráulicas medidas e simuladas, e os resultados obtidos permitiram verificar a consistência do modelo conceitual.
\end{abstract}

\begin{abstract}
In a hydrocarbon contaminated area located in Paulínia city (SP), lithological heterogeneity of local aquifer controls the migration of contaminant and the efficiency of pumping system. The aquifer consists of sedimentary rocks of Itararé Subgroup and Cenozoic sediments correlated to Rio Claro Formation. Therefore, understanding the heterogeinity that characterize the aquifer and its hydraulic properties is vital to optimization and improvement of remediation process. For hydrogeological characterization of the local aquifer, a conceptual hydrogeological model was elaborated by integrating traditional investigations tools, such as geophysical methods, piezometric level monitoring, geological descriptions and granulometric analysis; these data were used to understand the dynamic of the flow, the distribution of aquifer lithotypes and its hydraulic conductivity. Numerical simulations under steady-state condition using Visual Modflow were performed to test the conceived conceptual model. The measured and calculated hydraulic heads are in excellent agreement, showing the consistency of the conceptual model.
\end{abstract}

\section{INTRODUÇÃO}

A existência de contaminação de hidrocarbonetos em fase livre sobrenadante ao aqǘfero, em uma área industrial localizada no município de Paulínia (SP), tem suscitado investigações detalhadas na busca de solução para o problema.

Os mecanismos que governam a migração da pluma de contaminação são fortemente controlados pela complexa heterogeneidade litológica e hidráulica do aqüífero local. Desse modo, para subsidiar a otimização do sistema de remediação implementado, foram executadas investigações hidrogeológicas detalhadas.

De posse das informações obtidas por essas investigações, foi elaborada uma caracterização hidrogeológica da área de estudo. O emprego de modelos matemáticos de fluxo permitiu testar o modelo conceitual previamente concebido pela caracterização hidrogeológica. Assim, foi possível avaliar se os dados existentes até o momento permitem um entendimento satisfatório das características hidrogeológicas locais.

\section{OBJETIVOS}

Face à situação de contaminação na área sob investigação, este trabalho teve dois grandes objetivos:

- Caracterização Hidrogeológica, a partir da análise e interpretação dos dados obtidos em investigação detalhada, a fim de subsidiar o entendimento do complexo arcabouço geológico local e suas características hidráulicas, bem como da dinâmica de fluxo do aqǘf́ero presente na área de estudo;

- Simulação Numérica de Fluxo da Água Subterrânea, visando testar e ajustar o modelo conceitual previamente concebido no processo de caracterização hidrogeológica, bem como fornecer ferramentas que subsidiem a previsão de situações posteriores à operação da remediação da área em estudo.

${ }^{1}$ Programa de Pós-graduação em Geociêcias e Meio Ambiente - UNESP - Campus de Rio Claro (eh_teramoto@yahoo.com.br)

${ }^{2}$ Departamento de Geologia Aplicada - UNESP - Campus de Rio Claro (chang@rc.unesp.br) 


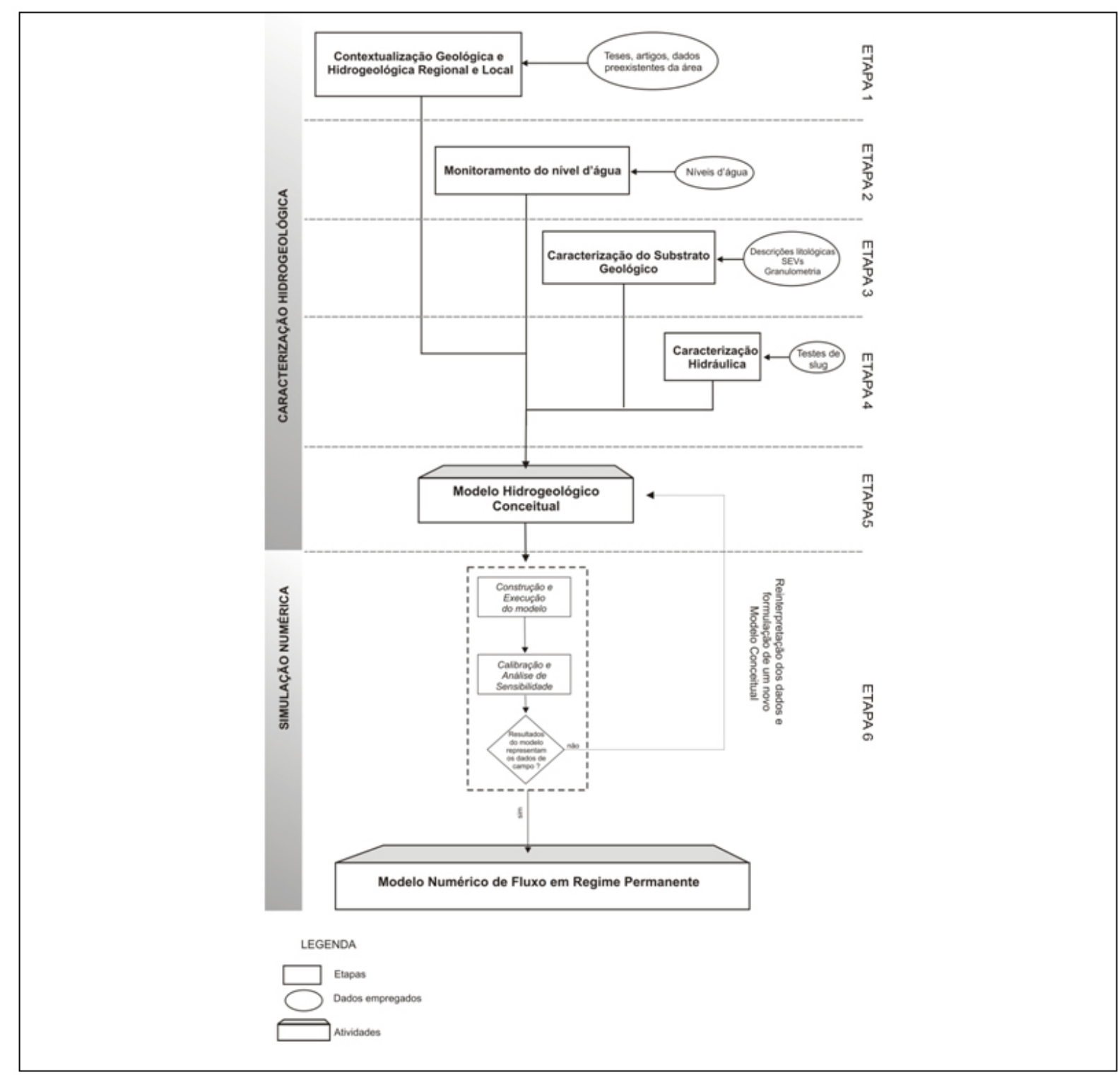

Figura 1 - Fluxograma com as etapas de trabalho e os dados utilizados em cada uma das etapas de trabalho.

\section{METODOLOGIA E DADOS UTILIZADOS}

O desenvolvimento dos trabalhos se deu em 6 etapas pré-definidas, em que diferentes métodos foram aplicados na coleta de dados.

Etapa 1 - Levantamento Bibliográfico de dados geológicos e hidrogeológicos locais e regionais, a partir de análise bibliográfica de teses, artigos e relatórios existentes sobre a área estudada;

Etapa 2 - Monitoramento do nível d'água, a partir do acompanhamento periódico da carga hidráulica em poços de monitoramento;

Etapa 3 - Caracterização geológica de subsuperfície utilizando descrições de sondagens e o método geoelétrico de sondagens elétricas verticais (SEVs);
Etapa 4 - Caracterização hidráulica do aqüífero por meio da identificação dos valores de condutividade hidráulica, mensurados a partir de testes de slugs;

Etapa 5 - Formulação de um modelo hidrogeológico conceitual a partir da integração das informações levantadas nas etapas anteriores;

Etapa 6 - Simulação numérica de fluxo por meio do método das diferenças finitas em regime permanente, com a utilização do software Visual Modflow ${ }^{\circledR}$.

As etapas de trabalho e os dados utilizados para sua realização encontram-se resumidamente representados na figura 1 . 


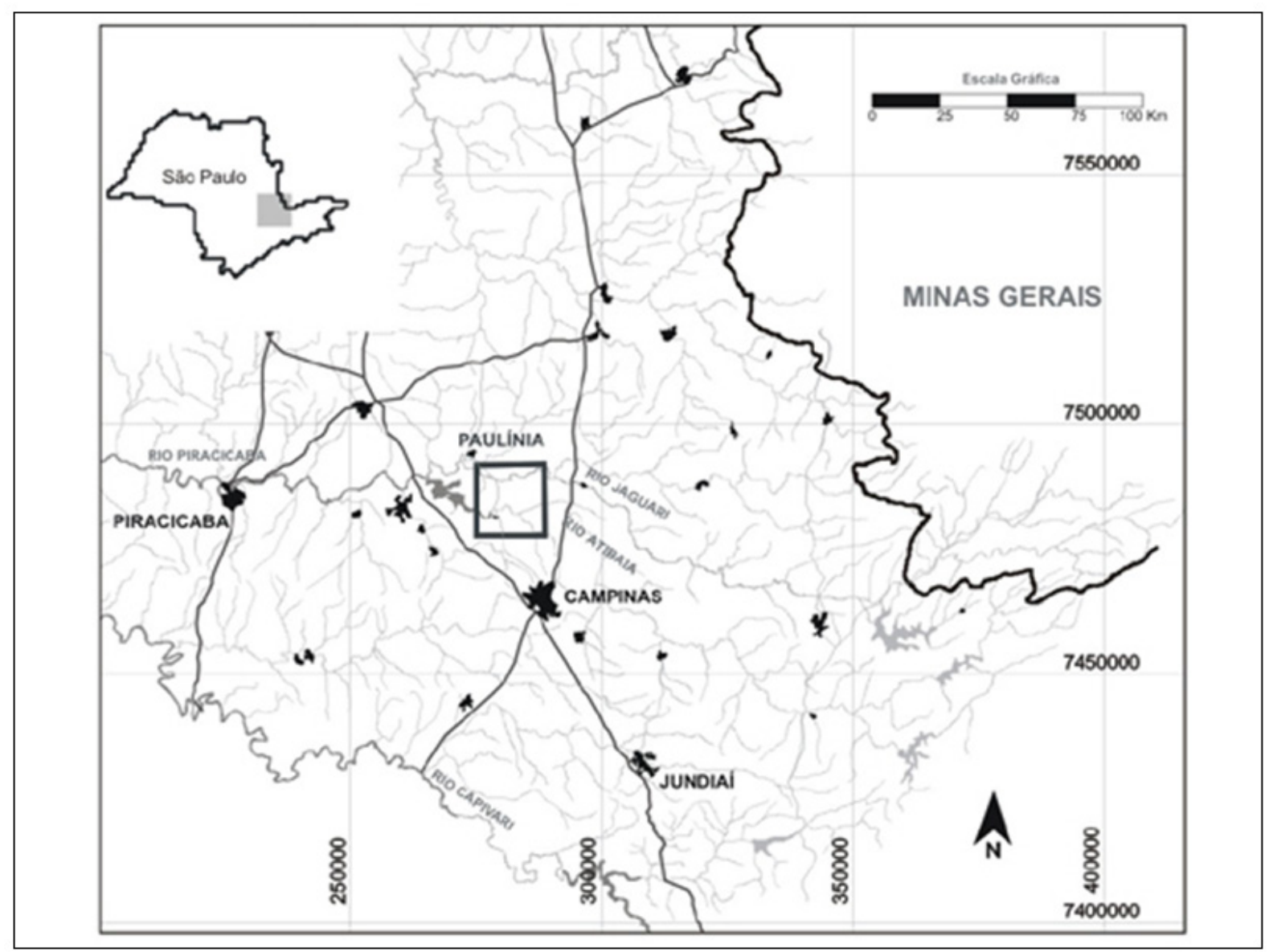

Figura 2 - Localização da área de estudo.

A área de estudo dista aproximadamente 130 Km da cidade de São Paulo e está situada na região de Campinas, porção nordeste do município de Paulínia (figura 2), próximo à borda da Bacia Sedimentar do Paraná. Quatro grandes unidades litoestratigráficas são encontradas na região (figura 3).

O Embasamento Cristalino é representado por granulitos-migmatitos-gnáissicos, ortognaisses e granitóides pré-cambrianos, pertencentes ao Grupo Amparo-Socorro.

O Subgrupo Itararé, de idade permo-carbonífera, é representado na área majoritariamente por rochas pelíticas de origem glácio-marinha, tais como siltitos, ritmitos, lamitos e diamictitos associados a lentes de areia de espessuras variáveis, assentados sobre rochas do Embasamento Cristalino, em contato erosivo e discordante, ostentando mergulhos regionais para oeste.

As Rochas Intrusivas Básicas, geneticamente relacionadas à Formação Serra Geral, de idade cretácea, ocorrem na forma de grandes soleiras e diques, alojadas nas rochas do
Subgrupo Itararé. As espessuras ostentadas por estas rochas variam de poucos metros a mais de $200 \mathrm{~m}$.

Os Depósitos Cenozóicos são correlacionáveis à Formação Rio Claro, de origem fluvial, descrita inicialmente na região do município de Rio Claro (SP) por Bjornberg \& Landim (1966). Na região em que se insere a área de estudo, destaca-se o trabalho de Fernandes (1997), que segmenta esses depósitos em 8 fácies de origem fluvial. Depósitos cenozóicos mais recentes, holocênicos, formam extensos terraços aluviais quaternários, distribuídos ao longo dos rios Atibaia e Jaguari.

\section{CARACTERIZAÇÃO HIDROGEOLÓGICA LOCAL}

Para a caracterização hidrogeológica foram utilizados dados coletados de 46 poços de monitoramento, com informações oriundas de testes de slug e medições de nível d'água. A localização relativa dos poços de monitoramento e bombeamento está ilustrada na figura 4 . 


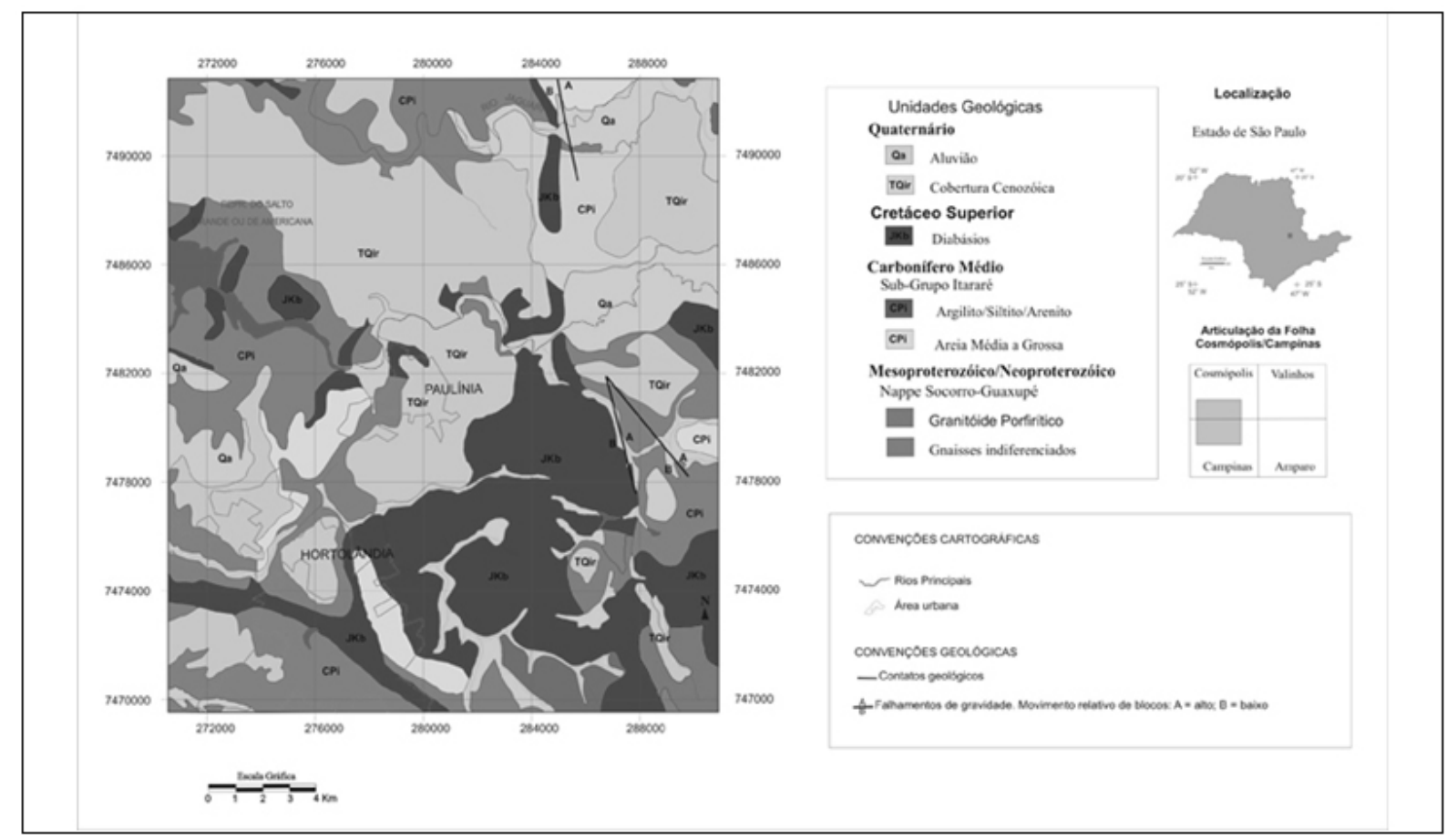

Figura 3 - Mapa Geológico Regional (modificado de FERNANDES, 1997).

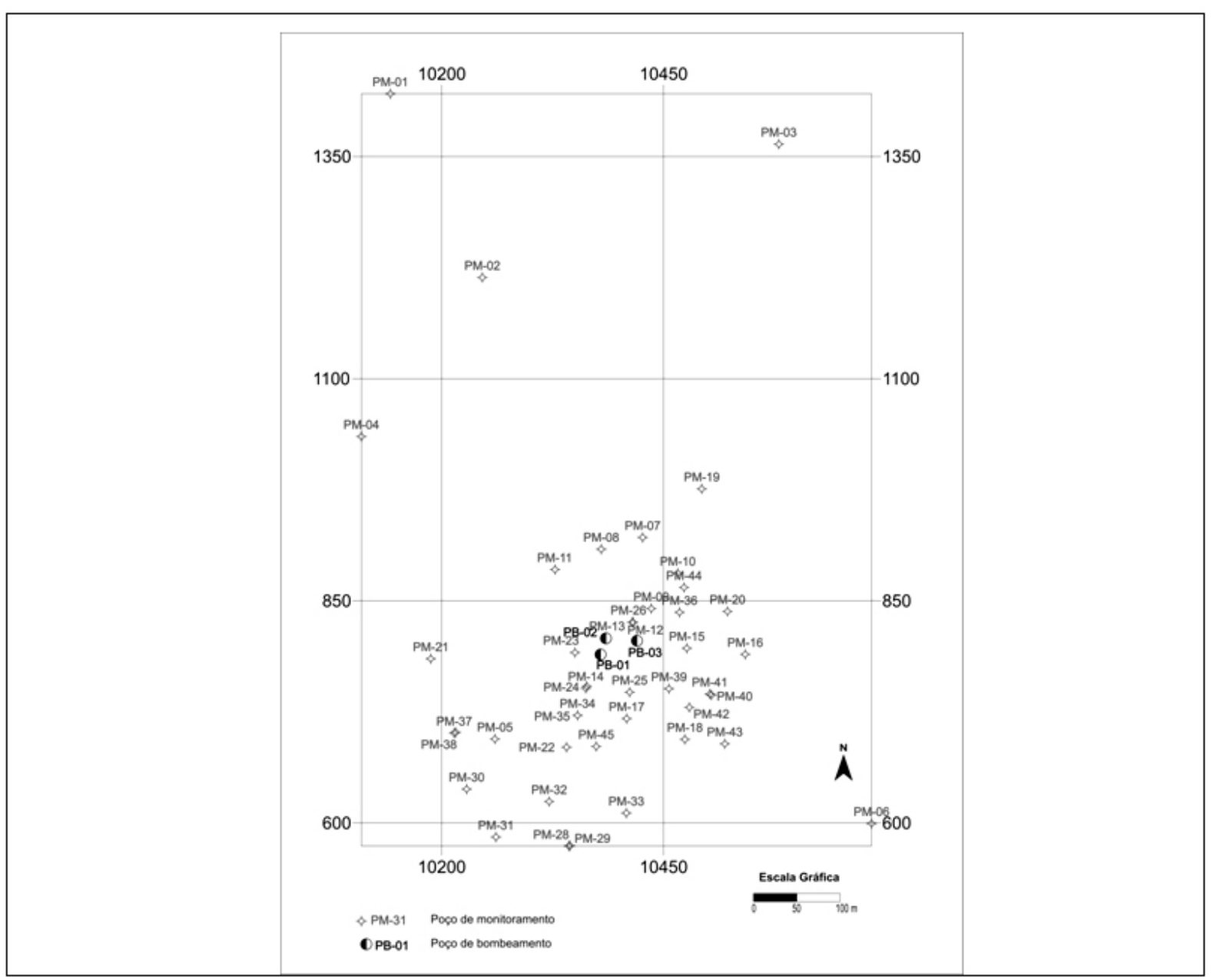

Figura 4 - Localização dos poços de monitoramento e bombeamento utilizados neste trabalho. 


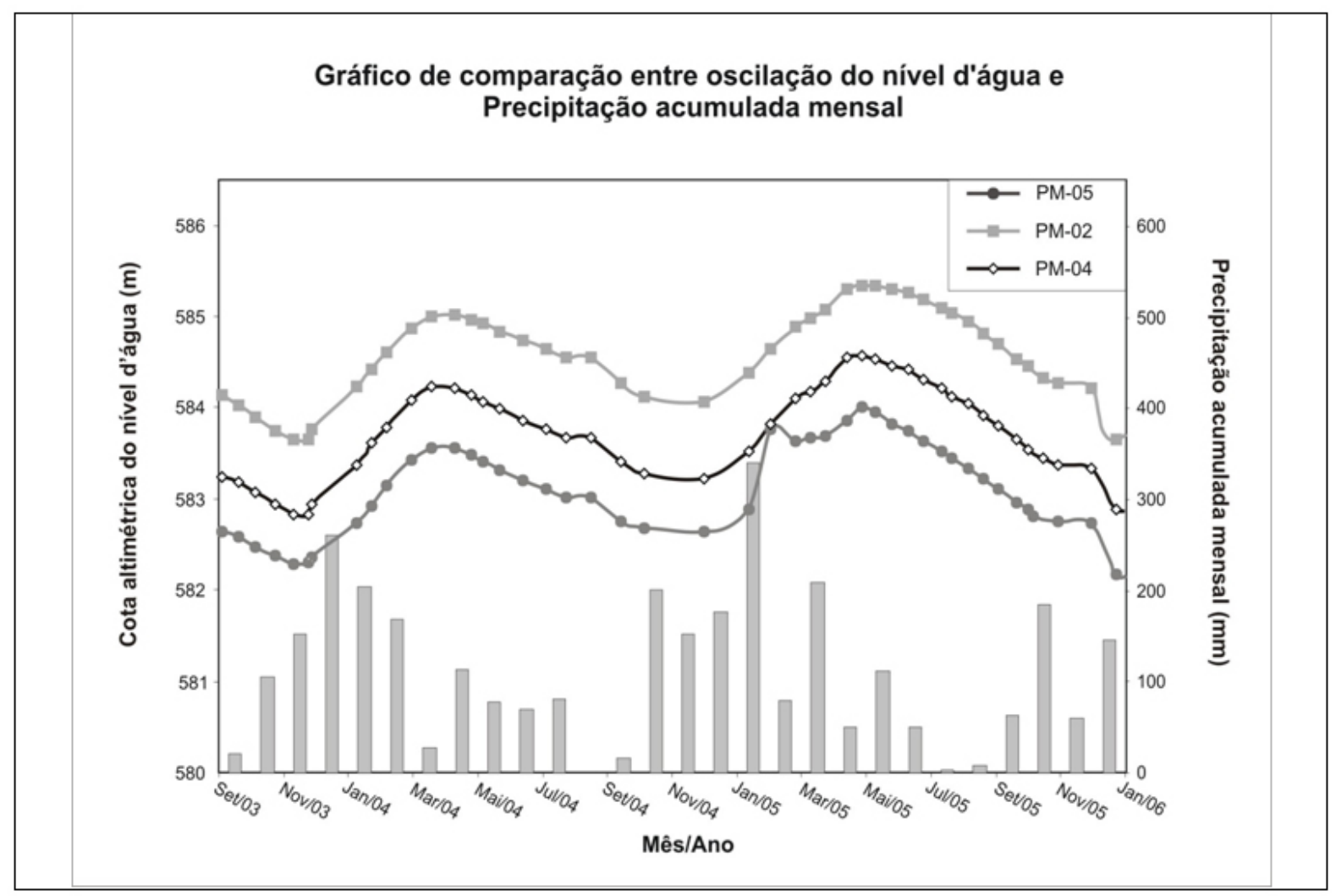

Figura 5 - Comparação entre as precipitações acumuladas mensais e as hidrógrafas de 3 poços de monitoramento.

\section{Nível d'água e Potenciometria}

A partir dos dados referentes às cargas hidráulicas adquiridas pela leitura periódica quinzenal dos níveis d'água nos poços de monitoramento, foi possível avaliar a variação temporal do nível piezométrico do aqüífero local, oriunda de oscilações de caráter sazonal ou induzidas pelo rebaixamento gerado pela operação dos poços de bombeamento.

Comparando-se o gráfico de oscilação do nível d'água com os valores de precipitação acumulada mensais, nota-se que existe um descompasso de aproximadamente 4 meses entre o período em que se verificam os maiores valores de precipitação e a máxima ascensão das hidrógrafas dos poços de monitoramento, como ilustrado na figura 5 .

A presença de poços multiníveis, com filtros instalados em diferentes profundidades, permitiu verificar que as superfícies equipotenciais na área são aproximadamente verticais, com fluxos horizontalizados. Isto indica que não ocorrem condições de confinamento entre os diferentes litotipos do aqüífero.

A figura 6 apresenta os mapas potenciométricos gerados a partir de dados obtidos das leituras de nível d'água de 20/12/2005 e 11/05/2006; observa-se um elevado incremento de gradiente hidráulico na porção sul da área, resultado da ação conjugada de litologias menos permeáveis aí existentes e da proximidade com a zona de descarga, representada por um córrego situado à jusante da área investigada.

\section{CARACTERIZAÇÃO GEOLÓGICA DO AQÜÍFERO}

Durante as perfurações das sondagens, os litotipos que compõem o aqǘfero local foram individualizados e caracterizados quanto à sua composição textural e distribuição relativa.

Independente das unidades litoestratigráficas a que pertencem, foram identificados sete litotipos, conforme abaixo descritos.

Litotipo A - Solo areno-argiloso a argiloarenoso vermelho, com espessura variando de 9 a $11 \mathrm{~m}$.

Litotipo $B$ - Depósitos coluvionares, siltoargilosos a silto-arenosos, com fragmentos laterizados de siltito. As espessuras desse litotipo variam de $0,5 \mathrm{~m}$ a mais de $7 \mathrm{~m}$.

Litotipo $C$ - Areia grossa argilosa cinza, vermelha e amarela. Apresenta espessura em torno de $1,5 \mathrm{~m}$ e encontra-se sobreposto a sedimentos dos litotipos D, E ou F. 


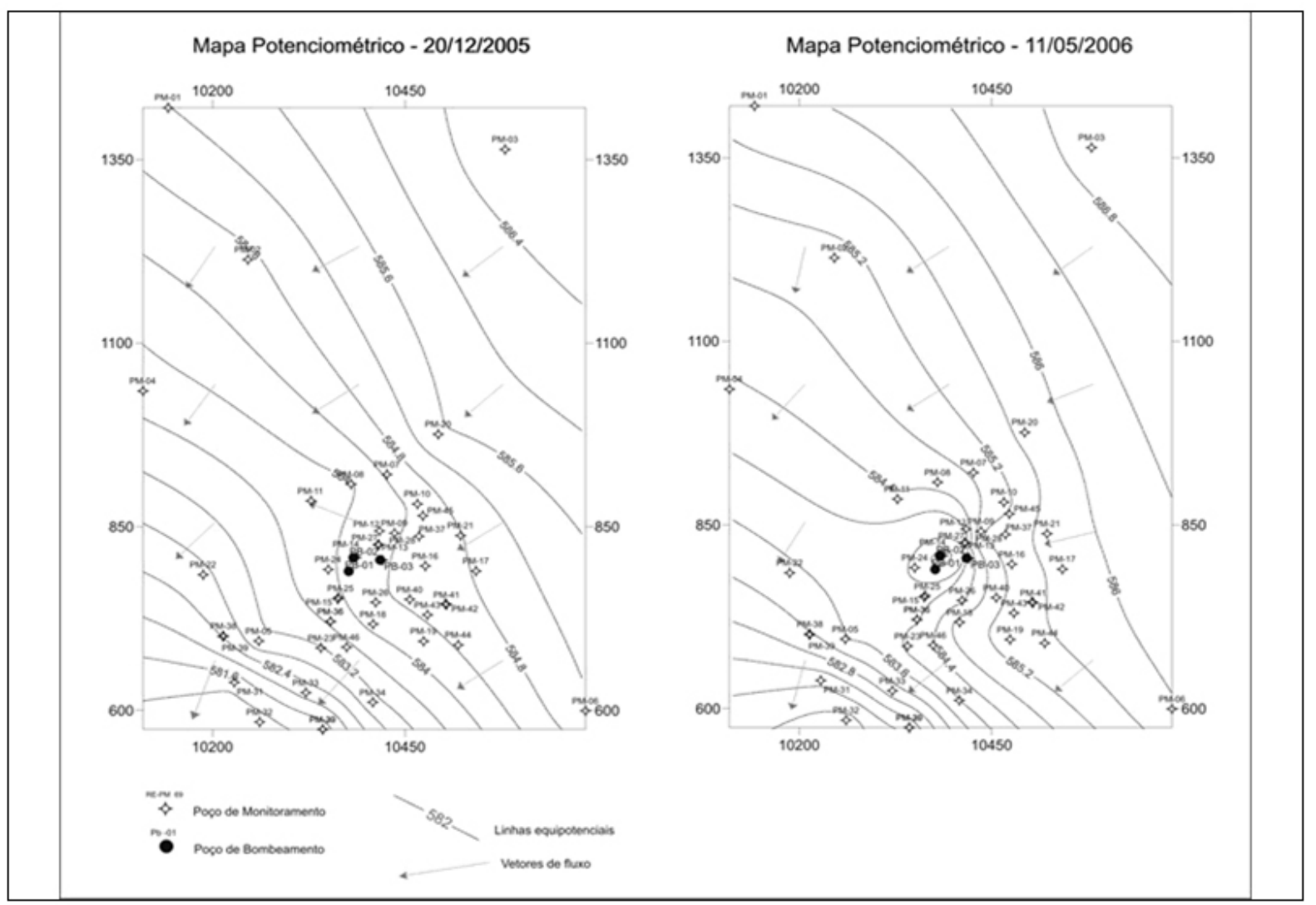

Figura 6 - Mapas potenciométricos dos dias 20/12/2005 e 11/05/2006.

Litotipo $D$ - Areia média a grossa, por vezes conglomerática, com espessuras variando de 1,5 m a 3,0 m. Sobrepõe-se aos siltitos argilosos do litotipo $\mathrm{G}$.

Litotipo E-Areia média a grossa silto-argilosa, interdigitada com arenitos do litotipo D.

Litotipo $F$ - Sedimentos argilo-arenosos de coloração cinza, branca ou avermelhada, interdigitados com sedimentos dos litotipos E e D.

Litotipo $G-$ Siltito argiloso, maciço, pouco fraturado, e lamito com laminação plano-paralela, ostentando grau de litificação brando, por vezes apresentando indícios de laterização.

O litotipo A compreende a porção não-saturada do aqǘf́ro e sua relevância para o entendimento da dinâmica de fluxo local é restrita. Os litotipos B,C,D,E,F e G compõem o aqüífero local, que é do tipo livre em toda sua extensão.

A figura 7 apresenta seções geológicas ilustrando a distribuição dos diferentes litotipos identificados.

Utilizando o método geofísico de eletrorresistividade, por meio da técnica de SEV
(Sondagem Elétrica Vertical), foi possível ampliar significativamente o número de observações de subsuperfície. Assim, foram identificadas eletrofácies, cuja interpretação em termos texturais permitiu a associação com os litotipos descritos nos poços perfurados.

Dessa forma, as SEVs propiciaram investigações mais profundas do aqüífero, em profundidades não alcançadas pelos poços de monitoramento. Foi possível observar, então, que em porções mais profundas do aqüífero predominam litologias silto-argilosas e argilosas e, ainda, estimar a posição do topo do diabásio, que representa a base impermeável do aqüífero no modelo conceitual previamente estabelecido.

A figura 8 mostra a distribuição de resistividade na porção superior do aqǘ́fero, indicando zonas de baixa resistividade na porção norte da área, relacionadas à presença de litotipos argilosos, em oposição à porção sul, onde predominam elevados valores de resistividade, associados a litotipos mais arenosos. 


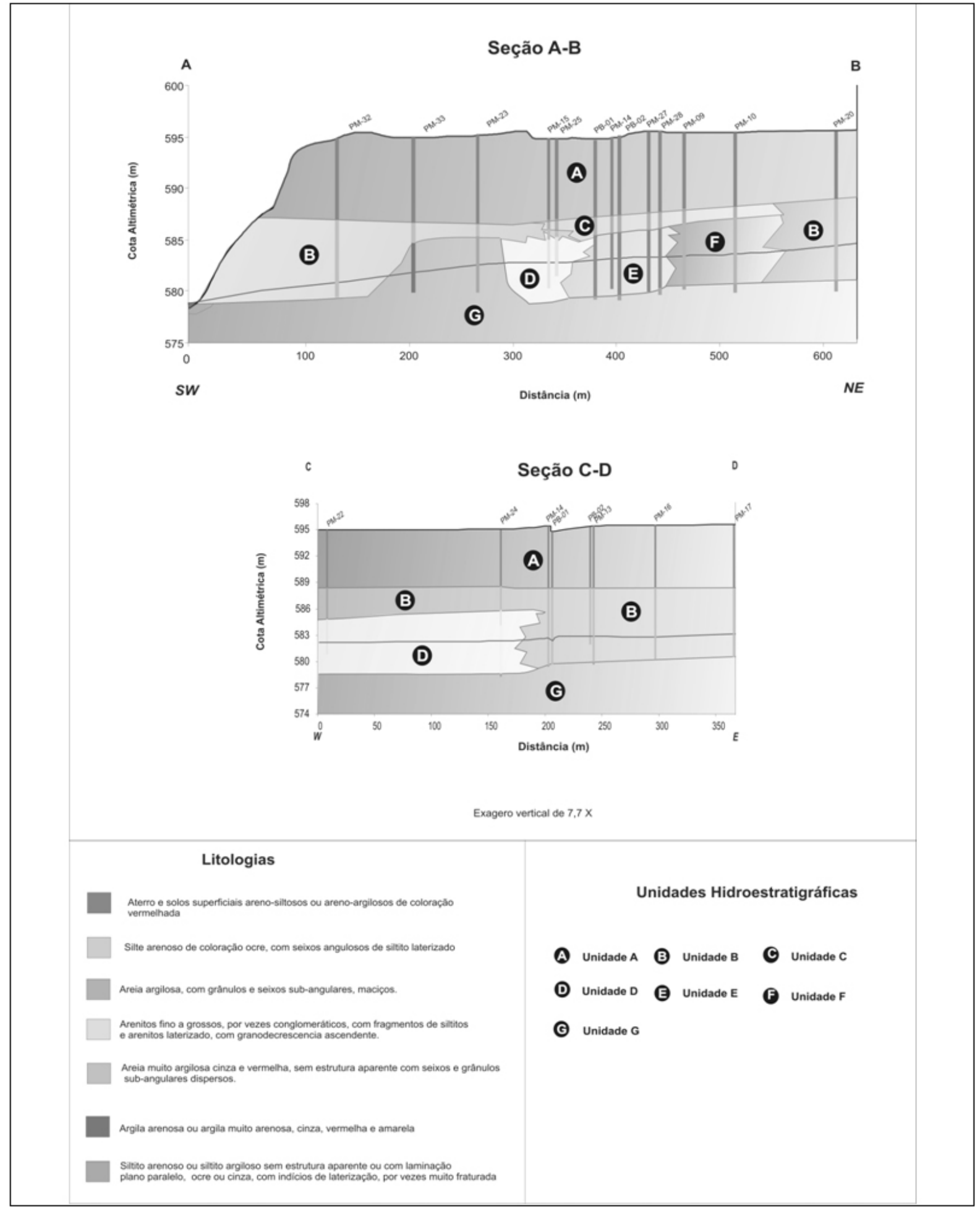

Figura 7 - Seções geológicas da área de estudo. 


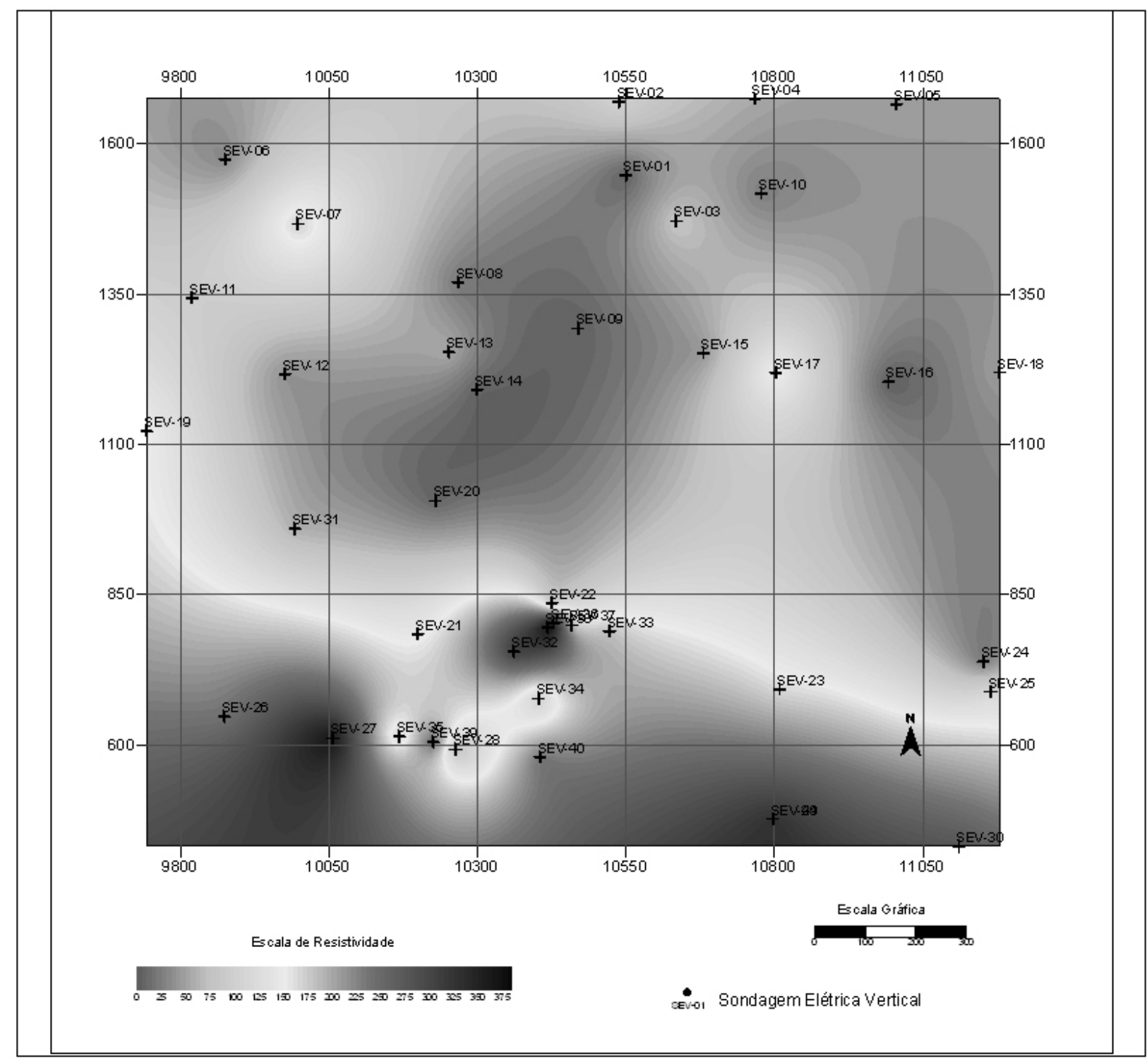

Figura 8 - Mapa de resistividade do primeiro horizonte saturado, mostrando a separação entre as zonas que representam as unidades.

\section{CARACTERIZAÇÃO HIDRÁULICA DA PORÇÃO SATURADA DO AQÜÍFERO LOCAL}

A identificação dos valores de condutividade hidráulica na área de estudo foi empreendida utilizando-se testes de slug, cujos aspectos teóricos e técnicos dos ensaios são detalhados no trabalho de Pede (2004).

Como mencionado anteriormente, o aqüífero local se caracteriza por forte heterogeneidade, fato este que induz a uma grande variação nos valores de condutividade hidráulica, cujas diferenças alcançam várias ordens de grandeza.
A figura 9 apresenta o histograma com as classes, em escala logarítmica, dos valores de condutividade hidráulica, mostrando uma distribuição bimodal. As classes mais freqüentes de K são aquelas correspondentes aos valores de $10^{-6} \mathrm{~m} / \mathrm{s}$ e $10^{-4} \mathrm{~m} / \mathrm{s}$.

A tabela 1 apresenta valores médios de condutividade hidráulica determinados pelos testes de slug para diferentes hidrofácies. Essas hidrofácies são o resultado da identificação das eletrofácies, obtidas das SEVs, associadas a diferentes litotipos e valores médios de condutividade hidráulica. 


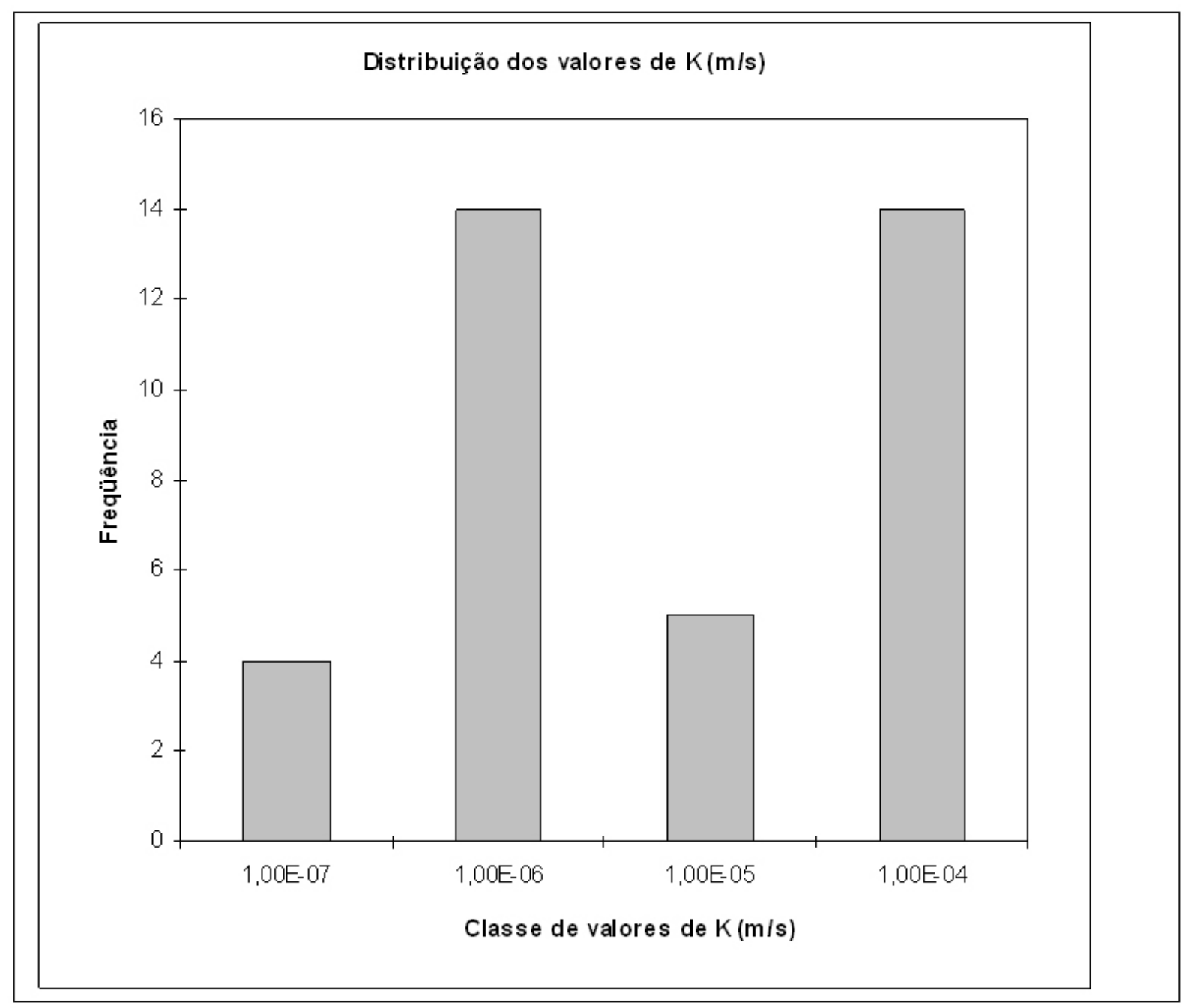

Figura 9 - Gráfico com a distribuição dos valores de $K(\mathrm{~m} / \mathrm{s})$.

Tabela 1 - Valores de condutividade hidráulica atribuídos a hidrofácies identificadas na área de estudo.

\begin{tabular}{|c|c|c|c|c|}
\hline Hidrofácies & Kmédio $(\mathbf{m} / \mathbf{s})$ & Kminimo $(\mathbf{m} / \mathbf{s})$ & Kmáximo(m/s) & $\mathbf{N}^{\mathbf{0}}$ de ensaios \\
\hline $\begin{array}{c}\text { areia média a } \\
\text { grossa }\end{array}$ & $1,670 \mathrm{E}-04$ & $2,590 \mathrm{E}-04$ & $1,080 \mathrm{E}-04$ & 14 \\
\hline areia argilosa & $1,940 \mathrm{E}-05$ & $2,543 \mathrm{E}-05$ & $1,090 \mathrm{E}-05$ & 5 \\
\hline silte argiloso & $3,460 \mathrm{E}-06$ & $7,700 \mathrm{E}-06$ & $1,210 \mathrm{E}-06$ & 14 \\
\hline argila arenosa & $4,980 \mathrm{E}-07$ & $4,050 \mathrm{E}-07$ & $4,053 \mathrm{E}-07$ & 2 \\
\hline siltito & $4,510 \mathrm{E}-07$ & $5,450 \mathrm{E}-07$ & $5,910 \mathrm{E}-07$ & 2 \\
\hline
\end{tabular}

Os maiores valores de condutividade hidráulica estão associados aos sedimentos do litotipo D (hidrofácies areia média a grossa), cuja ocorrência está restrita a uma faixa contínua na porção sul da área de estudo. Em oposição, os menores valores de $\mathrm{K}$ estão vinculados aos litotipos $\mathrm{F}$ e $\mathrm{G}$ (hidrofácies silte argiloso, argila arenosa e siltito).

Embora o litotipo $G$ seja caracterizado por valores bastante reduzidos de condutividade hidráulica, esses não impõem condição de confinamento às camadas subjacentes, sendo este fato comprovado por dados de poços multi-níveis. Deste modo, é mantida a classificação do litotipo $\mathrm{G}$ como unidade aqüífera.

A partir da análise de regressão linear múltipla aplicada a valores de condutividade hidráulica em função do diâmetro dos grãos, do grau de compactação e da porcentagem das classes granulométricas dos diferentes litotipos, obtevese a equação: 


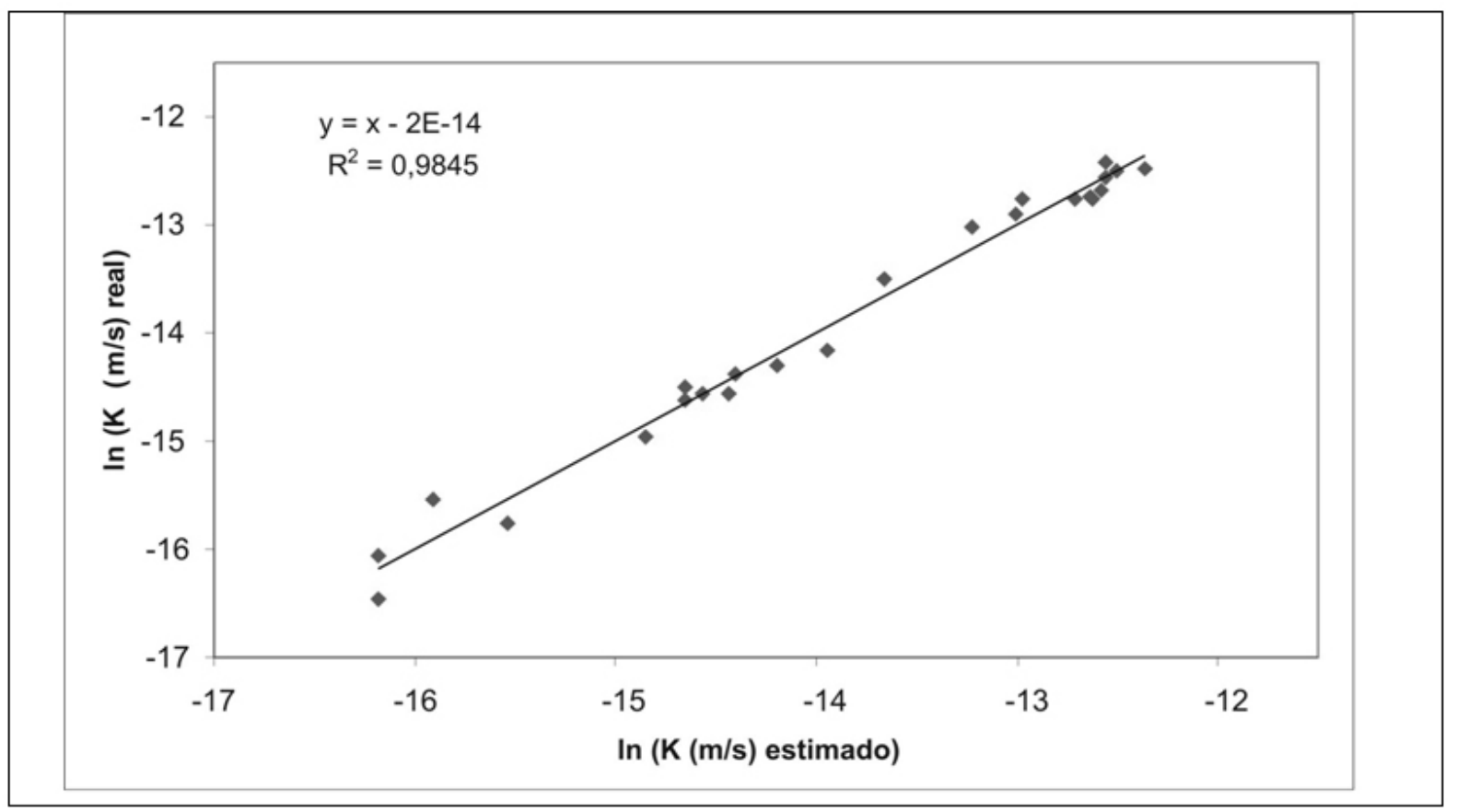

Figura 10 - Gráfico de dispersão de K obtidos em campo e os valores estimados pela regressão linear múltipla, mostrando elevada correlação.

$\operatorname{Ln}(\mathrm{K})=0,613 X_{1}+0,126 X_{2}-0,960 X_{3}-0,736 X_{4}$ $+0,794 X_{5}-1,014 X_{6}-0,146 X_{7}+0,669 X_{8}$

Nesta equação:

$X_{1}=$ diâmetro do grão correspondente a $60 \%$ (extraído da curva granulométrica);

$X_{2}=$ percentual de argila;

$X_{3}=$ percentual de silte;

$X_{4}=$ fator categórico, 0 para amostras friáveis e 1 para amostras compactas;

$X_{5}=$ percentual de areia média;

$X_{6}=$ percentual de areia fina;

$X_{7}=$ percentual de areia grossa;

$X_{8}=$ percentual de cascalhos.

A regressão entre os valores reais de $\mathrm{K}$ e aqueles calculados pela equação acima fornece um coeficiente de determinação $\mathrm{R}^{2}$ de $98,45 \%$ (figura 10) e um coeficiente de correlação $\mathrm{R}$ de $99,2 \%$. Estes resultados demonstram que a quase totalidade das variações dos valores de condutividade hidráulica pode ser explicada pela natureza textural do substrato aqüífero local e seu grau de compactação.

Esta equação forneceu informações adicionais de condutividade hidráulica, pois permitiu estimar valores em porções da área investigada onde se dispunha de amostras provenientes de sondagens, porém inexistiam poços de monitoramento e, portanto, sem informações de testes de slug.

\section{SIMULAÇÃO NUMÉRICA}

Simulação em regime permanente e resultados obtidos

De posse do modelo hidrogeológico conceitual, elaborado com base na caracterização hidrogeológica da área de estudo, foram realizadas simulações numéricas de fluxo empregando-se o método das diferenças finitas. Os aspectos teóricos presentes no processo de simulação numérica e as etapas envolvidas em sua execução podem ser encontrados em Wang \& Anderson (1982).

O modelo conceitual previamente estabelecido foi representado de maneira simplificada dentro do modelo matemático, como ilustrado esquematicamente na figura 11. O aplicativo utilizado para estas simulações foi o Visual Modflow 3.1.

O domínio simulado, com uma área total de $760000 \mathrm{~m}^{2}$, foi segmentado em 140 colunas, 140 linhas e 2 camadas. 


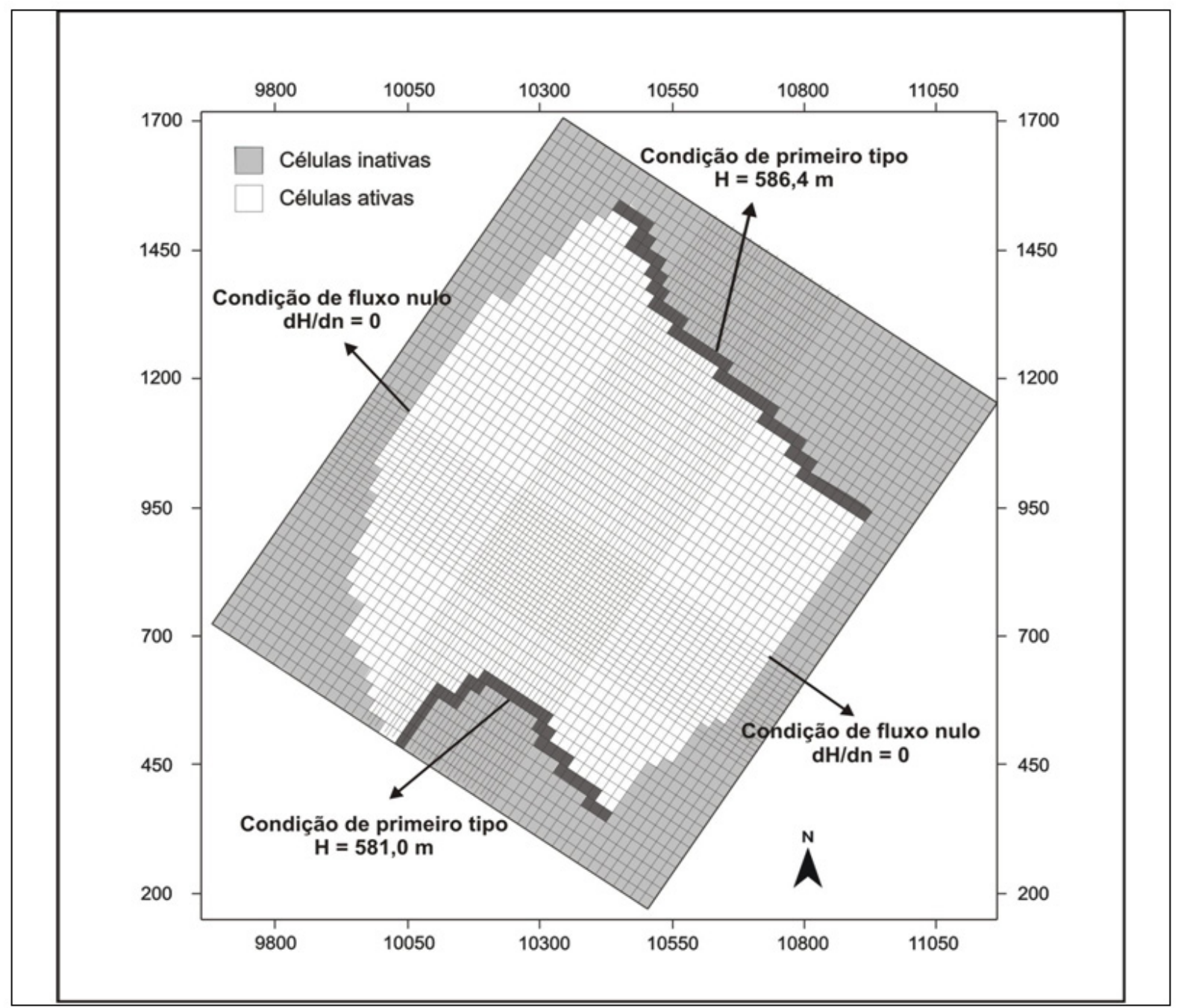

Figura 12 - Discretização do domínio simulado e localização das condições de contorno adotadas no modelo.

Para melhor representação dos poços de bombeamento operantes, foram efetuados refinamentos na porção central do modelo. A base impermeável foi estimada à cota altimétrica de $570 \mathrm{~m}$, representando a média da cota altimétrica atribuída aos sills de diabásio presentes na área, determinada por métodos geofísicos.

Não foram encontrados, na área, elementos físicos como rios, lagos e divisores que pudessem ser utilizados como condições de contorno. Desse modo, foram empregados elementos retirados do mapa potenciométrico do dia 20/07/2005, ilustrado na Figura 6. Para as bordas sul e a norte foram atribuídos contornos de carga especificada, com valores respectivos de 581 e 586,4 metros, e para as bordas leste e oeste foram atribuídos contornos de fluxo ausente, paralelos às linhas de fluxo do mapa potenciométrico.

A figura 12 ilustra a discretização do domínio simulado, com a localização das condições de contorno adotadas no modelo.

A distribuição dos valores iniciais de condutividade hidráulica (figura 13) baseouse na distribuição dos litotipos identificada em subsuperfície, obtida a partir da descrição das sondagens e da utilização de método geofísico. Como apresentado na Tabela 1, às hidrofácies identificadas na área de estudo foram atribuídos valores médios de condutividade hidráulica. Estes valores médios de $\mathrm{K}$ foram utilizados na simulação numérica aqui empreendida. 


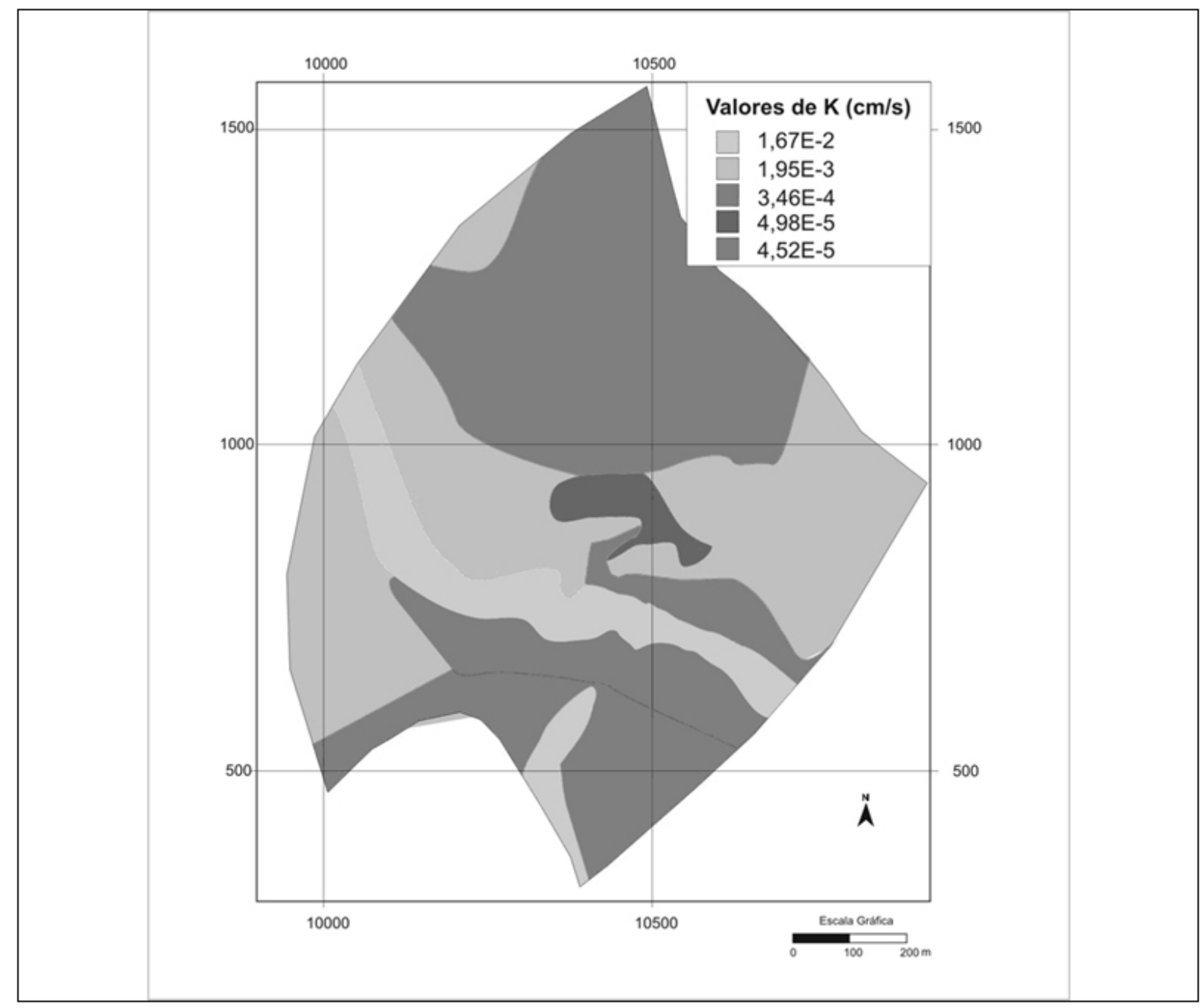

Figura 13 - Distribuição inicial de condutividade hidráulica na camada superior do domínio simulado.

Tabela 2 - Tabela com os valores dos principais parâmetros de calibração da simulação em regime permanente.

\begin{tabular}{|c|c|}
\hline Parâmetro de calibração & Valor obtido na calibração \\
\hline Resíduo médio & $0,009 \mathrm{~m}$ \\
\hline Resíduo absoluto médio & $0,103 \mathrm{~m}$ \\
\hline Erro padrão da estimativa & $0,026 \mathrm{~m}$ \\
\hline RMS (Root Mean Squared) & $0,129 \mathrm{~m}$ \\
\hline RMS normalizado & $3,069 \%$ \\
\hline $\begin{array}{c}\text { Coeficiente de correlação entre as cargas cal- } \\
\text { culadas pela simulação e reais }\end{array}$ & 0,992 \\
\hline
\end{tabular}

Os resultados da simulação, ilustrados na tabela 2, mostram correlação de 99,2\% entre os valores de carga hidráulica mensurados em campo e aqueles calculados pela simulação em regime permanente. Esses resultados indicam que os valores de condutividade hidráulica, recarga e taxas de bombeamento, empregados na simulação, permitiram uma representação similar das distribuições reais de carga hidráulica dentro do modelo.

A figura 14 permite a comparação entre as linhas equipotenciais geradas pela simulação e as equipotenciais do mapa potenciométrico obtido em campo. A sobreposição dos mapas potenciométricos real e gerado pela simulação demonstra a elevada correspondência entre ambos e atesta a representatividade do modelo simulado. 


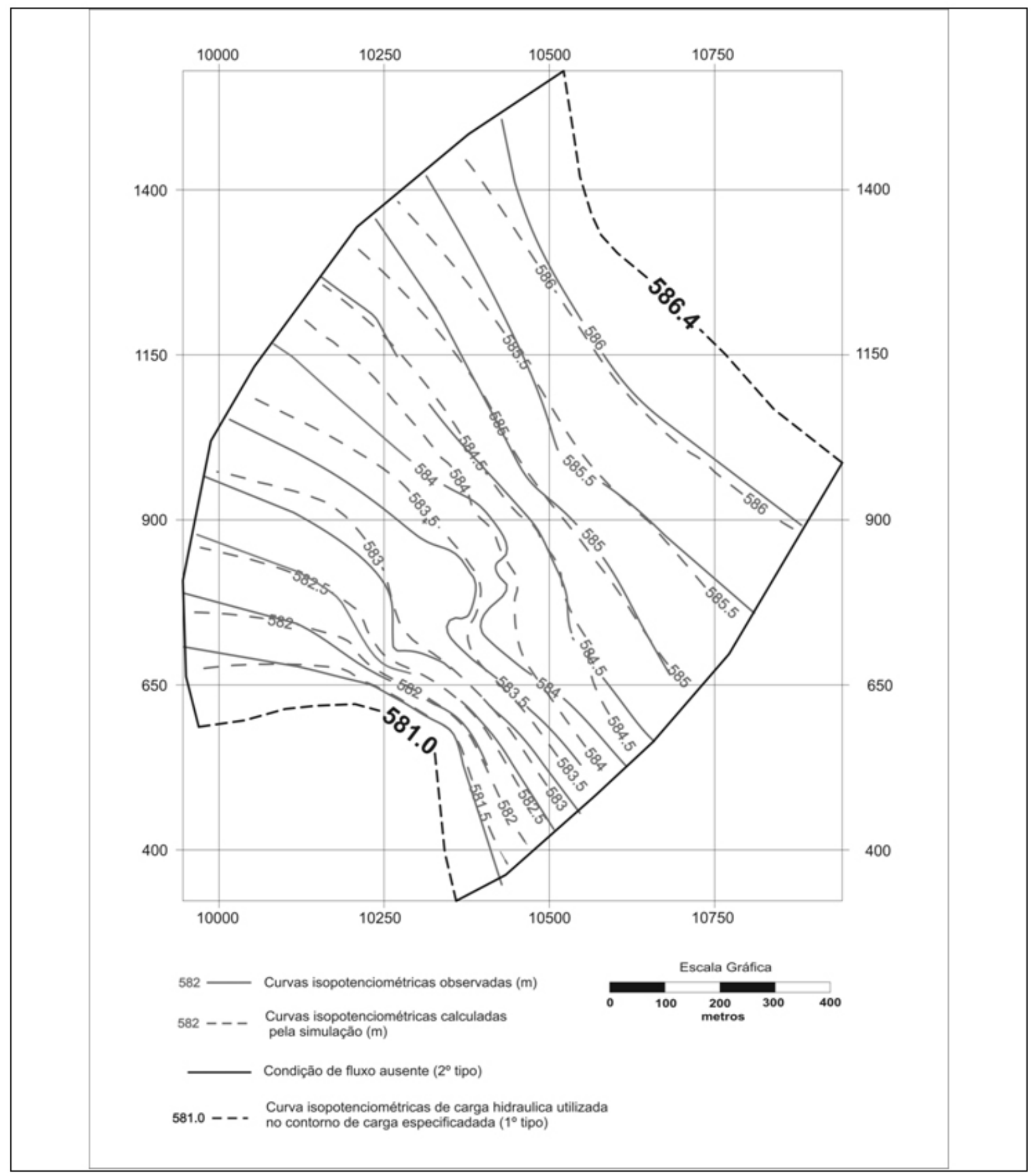

Figura 14 - Sobreposição das equipotenciais observadas e calculadas.

A figura 15 apresenta a distribuição dos valores de condutividade hidráulica após o processo de calibração e alteração dos valores iniciais de K, apresentados na figura 14. A distribuição dos valores de $\mathrm{K}$ iniciais e calibrados mostra forte similaridade, tanto espacialmente quanto nas classes de valores presentes. Este fato indica que o modelo conceitual inicialmente proposto se mostrou consistente, sendo desnecessárias mudanças significativas para alcançar a calibração do modelo.

\section{ANÁLISE DE SENSIBILIDADE}

Após a calibração, foram realizadas análises de sensibilidade do modelo, o que permitiu identificar o grau de dependência da solução do modelo frente a diversos parâmetros de entrada.

Foram efetuadas modificações de aproximadamente $20 \%$ nos valores dos diversos parâmetros de entrada do modelo (taxas de recarga, condutividade hidráulica e taxas de bombeamento) para avaliar a sensibilidade do modelo a esses parâmetros. 


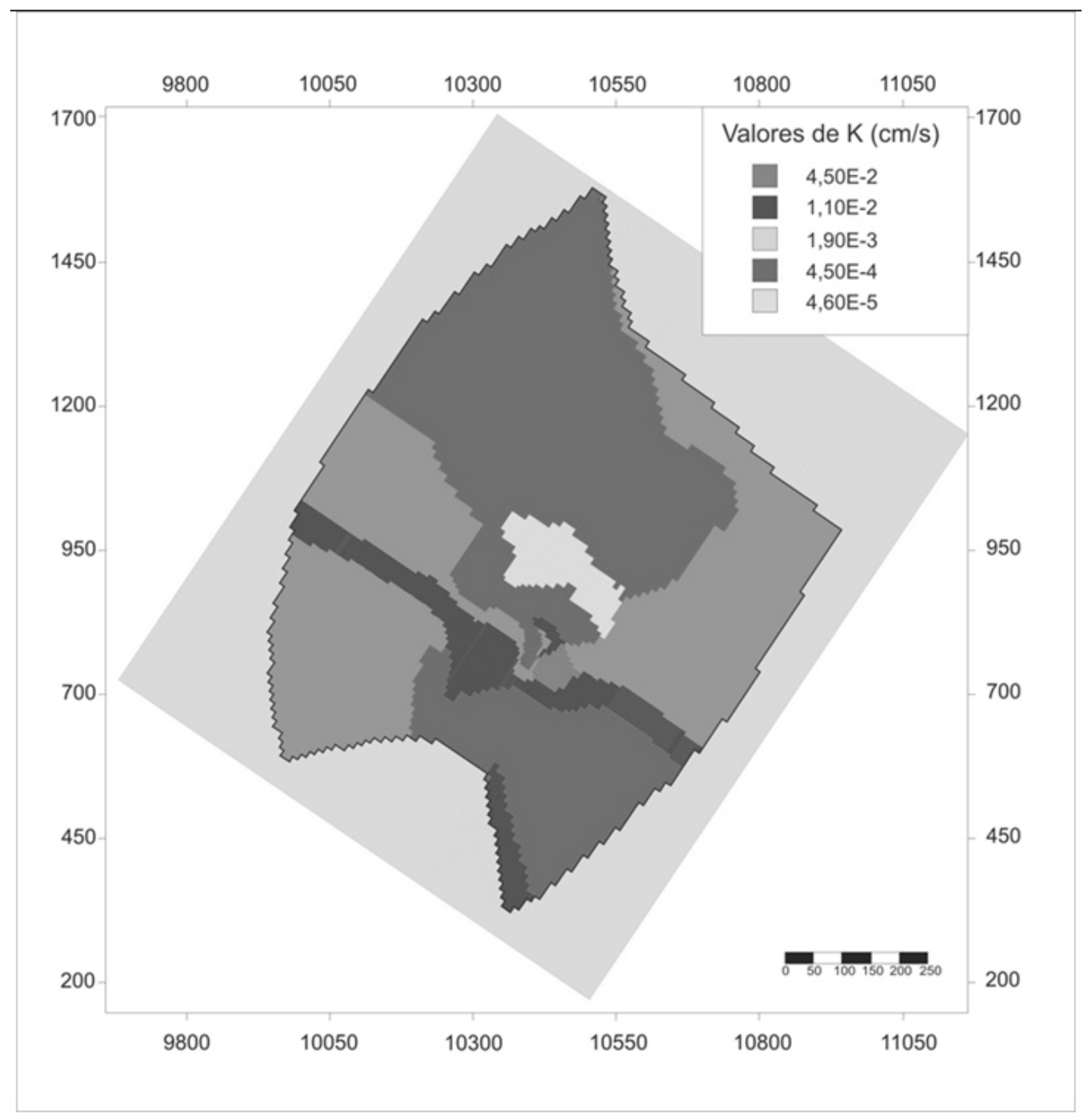

Figura 15 - Distribuição dos valores de condutividade hidráulica para a primeira camada, após a calibração do modelo.

A razão entre a variação dos valores de RMS e a variação dos parâmetros de entrada do modelo, também denominado coeficiente de sensibilidade, foi utilizada.

Os valores de coeficiente de sensibilidade, ilustrados na figura 16, são bastante reduzidos, com predominância de valores entre 0,005 e 0,050, indicando que, para perturbações significativas nos parâmetros de entrada do modelo, são identificadas influências pouco significativas em sua calibração.
Com vistas a avaliar, em termos relativos, a importância dos parâmetros de entrada do modelo, representado pelas taxas de recarga e bombeamento, foram realizadas simulações após a supressão destes parâmetros no modelo. Os resultados destas simulações encontram-se na tabela 3 .

Verifica-se que a recarga apresenta contribuição significativa na calibração do modelo e sua supressão induz a uma perda significativa de representatividade da solução. 


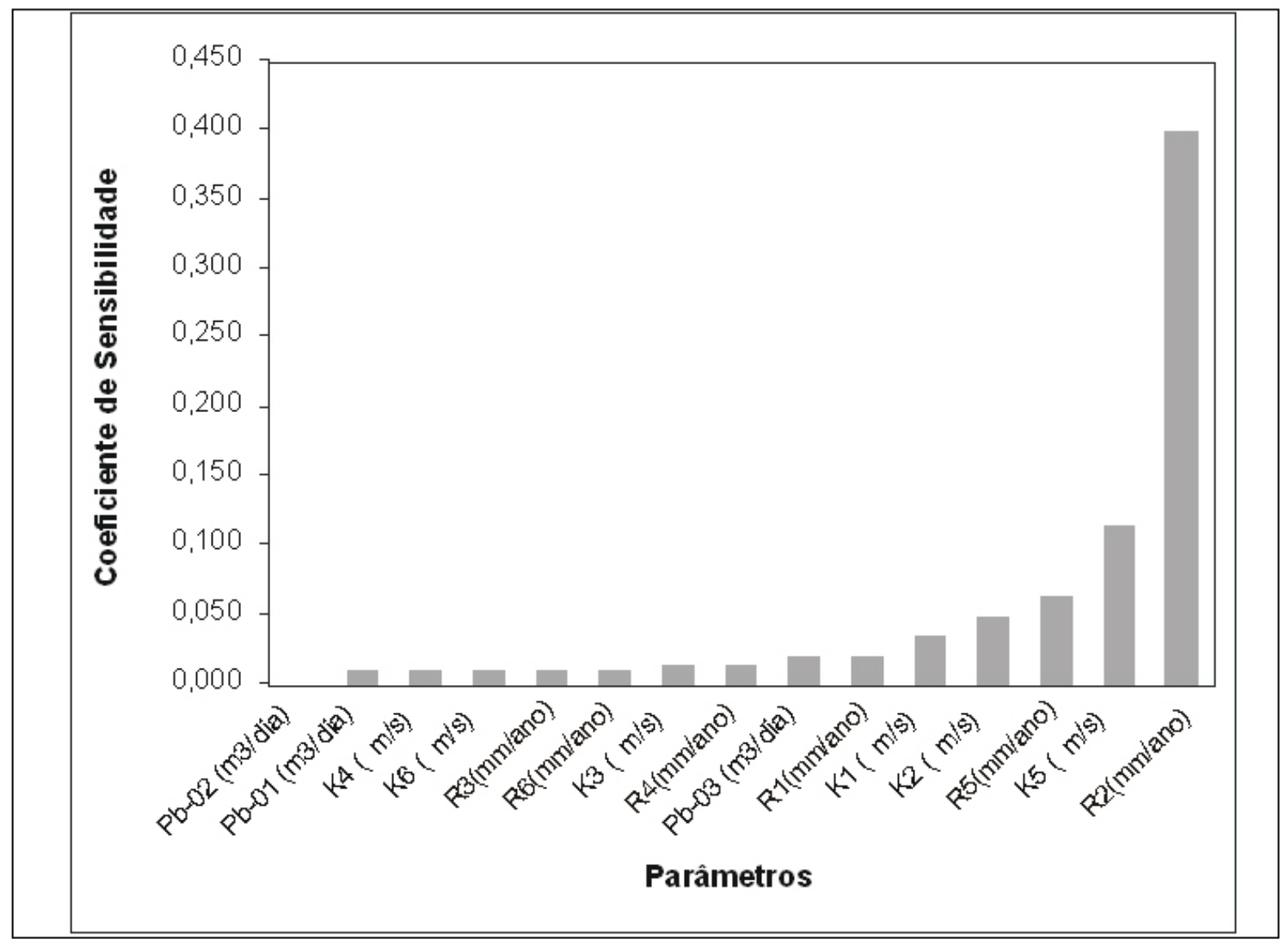

Figura 16 - Gráfico ilustrando os coeficientes de sensibilidade derivados de alterações dos diversos parâmetros de entrada do modelo. $\mathrm{Pb}$ - taxa de bombeamento $\left(\mathrm{m}^{3} /\right.$ dia $) ; \mathrm{K}$-condutividade hidráulica $(\mathrm{m} / \mathrm{s}) ; R$ - taxa de recarga (mm/ano)

Tabela 3 - Resultado dos incrementos dos resíduos gerados pelo acréscimo de carga hidráulica nos contornos de

\begin{tabular}{|c|c|c|c|}
\hline Parâmetro suprimido & RMS (m) & Norm. RMS (\%) & $\begin{array}{c}\text { Coeficiente de } \\
\text { correlação }\end{array}$ \\
\hline Recarga & 1,125 & 26,836 & 0,949 \\
\hline Bombeamento & 0,297 & 7,086 & 0,986 \\
\hline
\end{tabular}

Com a remoção deste parâmetro, o erro alcança o valor de $26,84 \%$, e o coeficiente de correlação entre os valores observados e calculados de carga hidráulica diminui para $94,90 \%$, diferindo substancialmente dos resultados originais.

Asupressãodosdadosdepoços de bombeamento induz a uma perda menos significativa na solução do modelo, sendo este fato decorrente da influência dos poços de bombeamento que se restringe a uma pequena porção da área simulada.

\section{CONCLUSÕES}

Os valores de condutividade hidráulica estão diretamente associados à natureza textural dos litotipos que compõem o arcabouço do aqüífero. Os testes de slug permitiram estimar esses valores e associá-los às hidrofácies identificadas na seção filtrante dos poços de monitoramento onde foram realizados os ensaios.

A quantidade e a qualidade das informações existentes permitiram um entendimento satisfatório da área estudada e a formulação de um modelo conceitual consistente, fato demonstrado pela elevada correspondência entre o modelo concebido previamente e aquele obtido pelo ajuste de parâmetros de entrada do domínio simulado.

Os resultados dos modelos em regime permanente de fluxo são representativos para as condições reais da área, pois apresentam as seguintes características:

- elevado coeficiente de correlação entre os valores de carga hidráulica de campo e aqueles calculados pela simulação, refletida pela conformação semelhante das 
linhas equiponteciais respectivas;

- os coeficientes da análise de sensibilidade mostraram-se reduzidos, evidenciando que as incertezas associadas aos diversos parâmetros de entrada do modelo, como valores de condutividade hidráulica, recarga e bombeamento, e a dependência do resultado da simulação frente a estes, são reduzidas.
Ao mesmo tempo em que o modelo numérico se presta para testar e validar o modelo conceitual, também auxilia no direcionamento de investigações adicionais e subsidia etapas seguintes de diagnóstico detalhado da área, bem como a simulação de transporte de contaminantes, uma vez que as heterogeneidades hidráulicas podem ser adequadamente representadas.

\section{REFERÊNCIAS}

BJORNBERG, A. E LANDIM, P. M. B. Contribuição ao estudo da Formação Rio Claro (neocenozóico). Boletim da Sociedade Brasileira de Geologia, 15 (4): p.43-67. São Paulo, 1966.

FERNANDES, A. J. Tectônica Cenozóica na Porção Media da Bacia do rio Piracicaba e sua Aplicação à Hidrogeologia. Tese (Doutoramento em Recursos Minerais e Hidrogeologia) - Instituto de Geociências, Universidade de São Paulo - São Paulo, 244 fls., 1997.

PEDE, M.A.Z. Caracterização da condutividade hidráulica do embasamento cristalino alterado saturado na região metropolitana de São Paulo. 2004. 95 f. Dissertação (Mestrado em Geociências) - Instituto de Geociências e Ciências Exatas, Universidade Estadual Paulista, Rio Claro, 2004.
WANG, H. F. e ANDERSON, M. P. Introduction to Growdwater Modeling:Finite Difference and Finite Element Methods. Sand Diego, Californica, USA: Academic Press. 237 p., 1982

\section{AGRADECIMENTOS}

Os autores agradecem Laboratório de Estudo de Bacias (LEBAC) - Departamento de Geologia Aplicada, associado ao Centro de Estudos Ambientais da UNESP, à FUNDUNESP, à CAPES e ao CNPq (350983/1997-6), pela concessão de bolsas e apoios recebidos na realização deste trabalho. 